شبيهسازى ذخاير آب در ساختار زىتوده اشكوب درختى جنگل هاى طبيعى و آميخته راش در شمال كشور با استفاده از تكنيك شبكه عصبى مصنوعى

\author{
على اصغر واحدى 1*

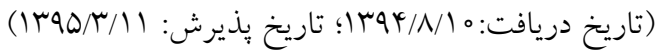

DOI: 10.18869 /acadpub.jstnar.20.78.53

جكيده

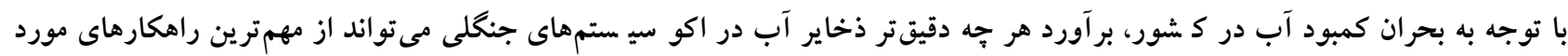

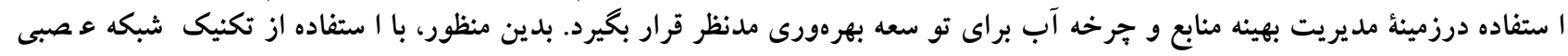

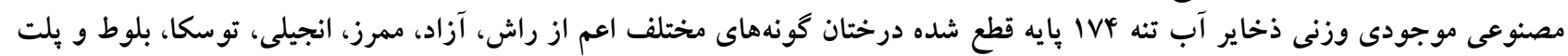

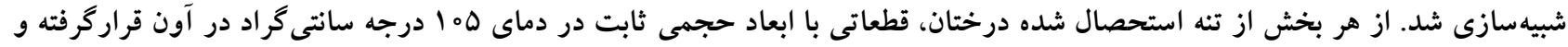

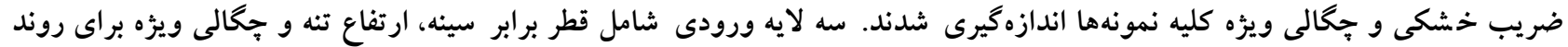

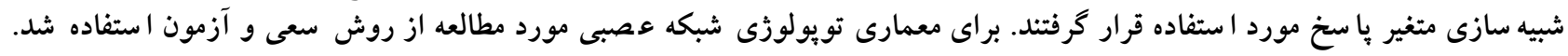

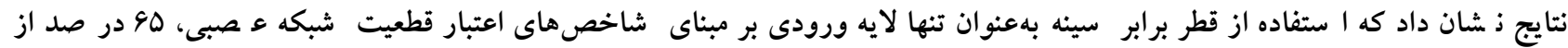

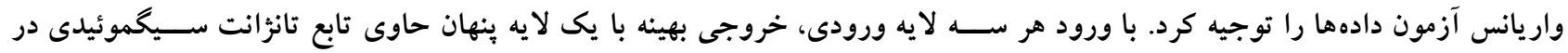

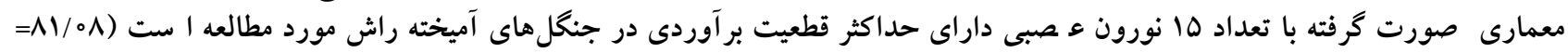
حاصل

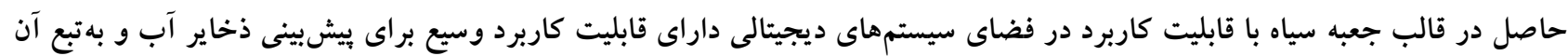

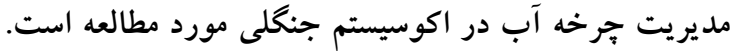

وازههاى كليدى: جنگل هاى آميخته راش، جنگلهاى هير كانى، جرخه آب، زى توده درختان، شبكه عصبى مصنوعى

1. مؤسسه تحقيقات جنگلها و مراتع كشور، سازمان تحقيقات، آموزش و ترويج كشاورزى، تهر ان

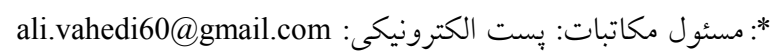


شــدن روزنه بركها در حين جذب كربن اتمسـفرى، آب وارد

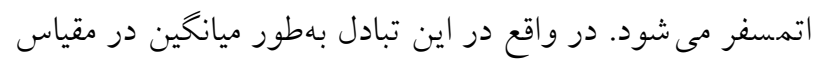

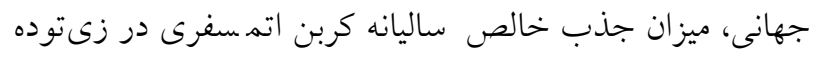

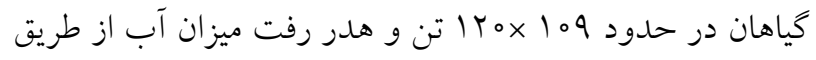

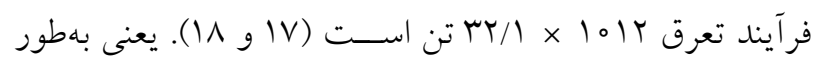

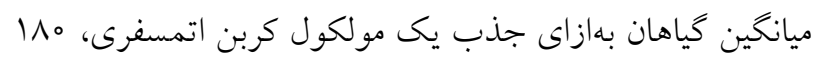

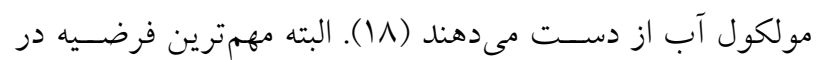
اين زمينه اين اسـت كه با افزايش حجم كربن در اتمســفر نرخ جذب كربن اتمسفرى تو سط درختان در جنكلها بيشتر شده و

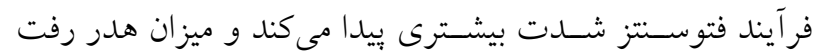

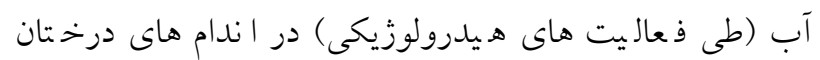
بهدليل افزايش شدت بهرهورى استفاده از آب ( WUE: Water بse efficiency واقع ميزان بيشترى از آب تو سط درختان جذب و در بافتهاى

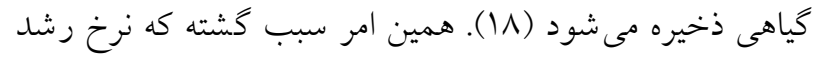

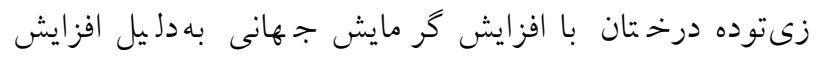

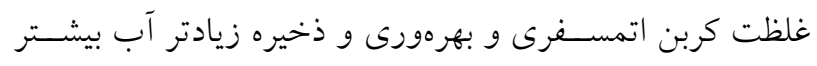

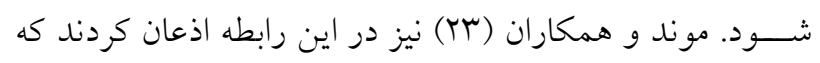

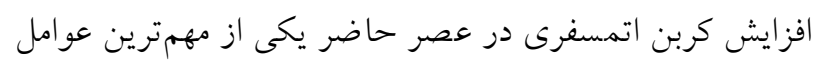

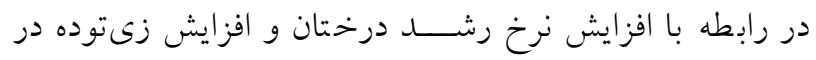
جنجالهاى ارويا است.

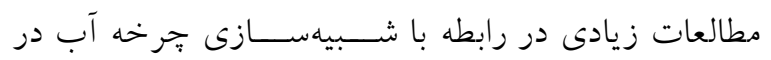
مقياس جهانى و منطقهاى براى در يا فت اطلاعات دقيق در

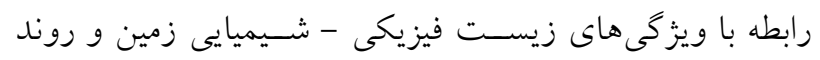

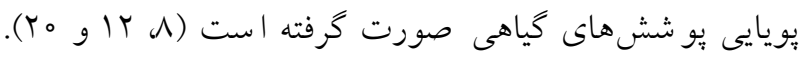

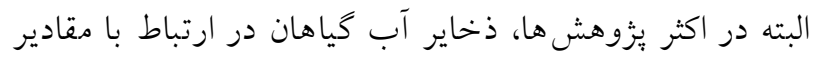
جذب كربن اتمسفرى و روند تبادلى آن در خرخههاى مختلف مدنظر قرار گرفتهاند. در واقع تخمين ذخاير موجود در منابع

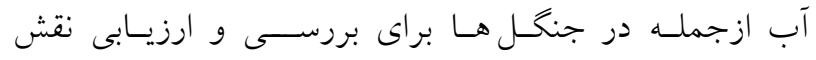

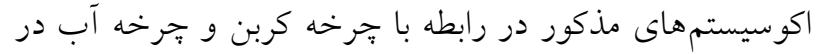

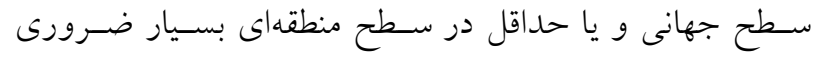

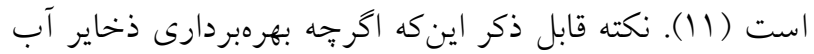

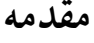

امروزه بحران كمبود آب و توزيع آن با توجه به خكشسالىهاى

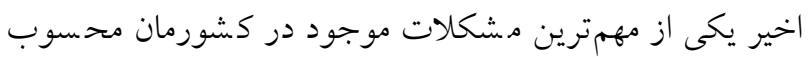

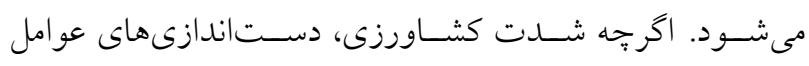
اذسانى و ضعف مديريت بهعنوان مهمترين عوامل كاهش منابع

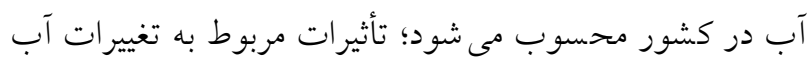

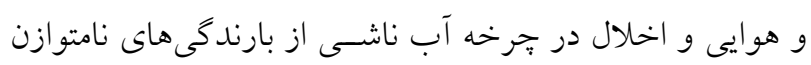

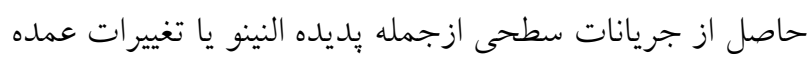

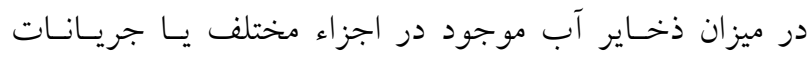

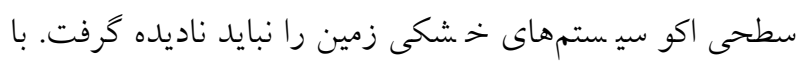

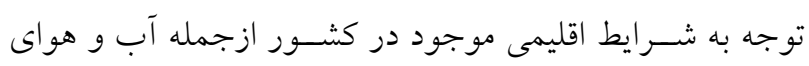

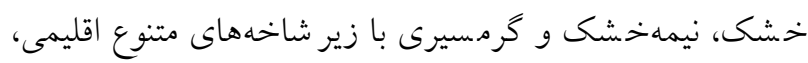

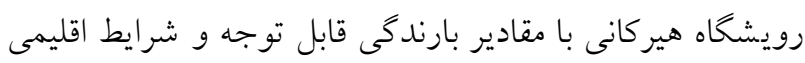

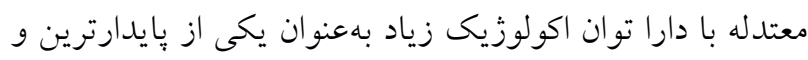

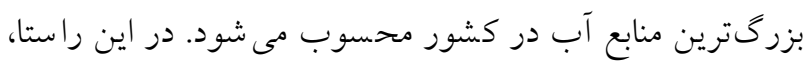
جنغل هاى هير كانى با بخش اعظم خاكهاى حاصلخيز، توليدات

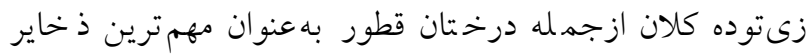

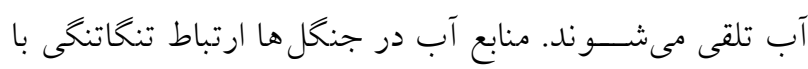

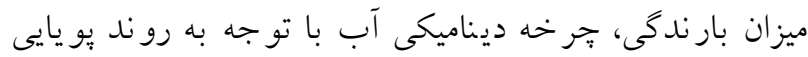

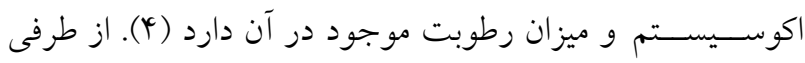

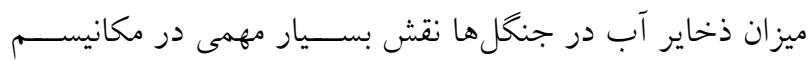

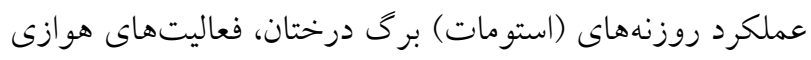
و غيرهوازى ميكروبى و بيولوزيكى خاك و ت تعادل كربن دارد بردي

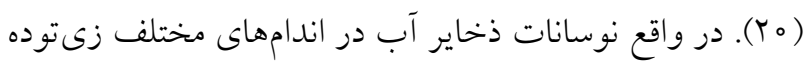

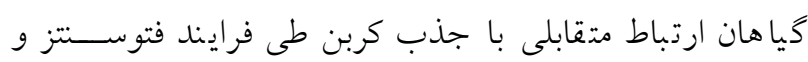

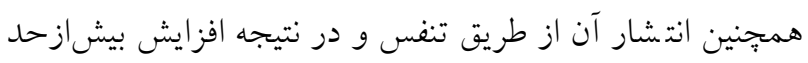

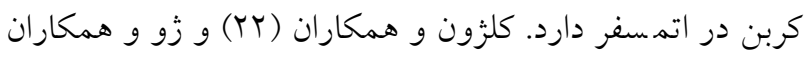

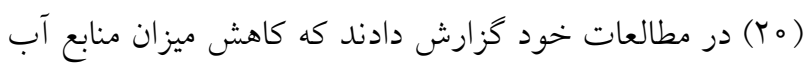

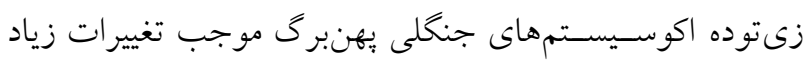

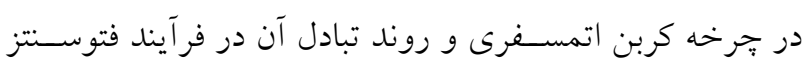

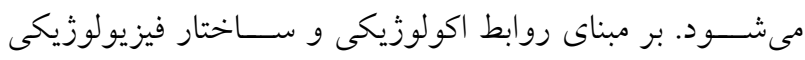
حاكم در زىتوده كياهان اكوسـيســـمهاى طبيعى جنشل، با باز 
مناســـب براى پِيش ت بادلات مـقادير آب بر مبناى رو ند

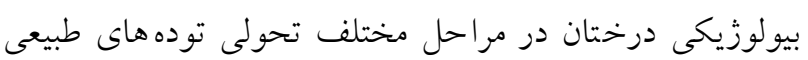

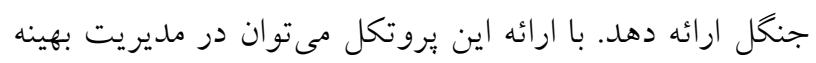

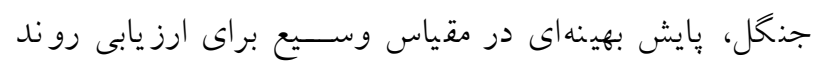

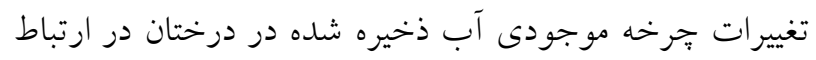
با نرخ رشد زىتوده و سناريوى گرمايش جهانى انجام داد.

\section{مواد و روشها منطقه مورد مطالعه}

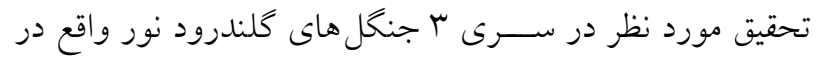

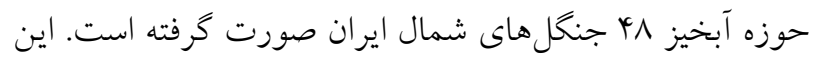
سرى از نظر تقسيمات ادارى در حوزه استحفاظى اداره كل منابع

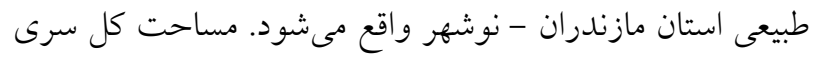

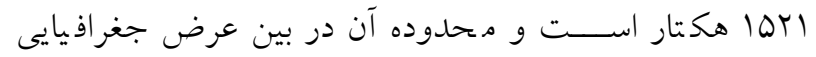

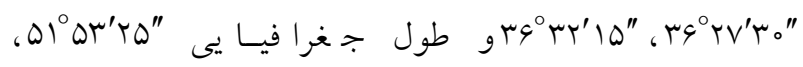
سه

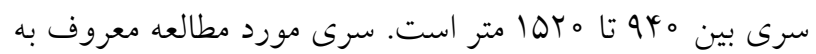

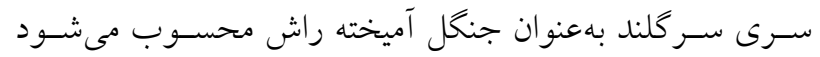

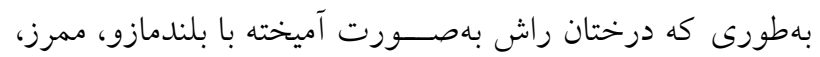

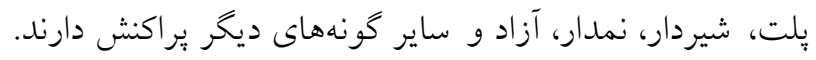
جهت عمومى در كل سرى غربى بوده و حداكثر شيب منطقه در

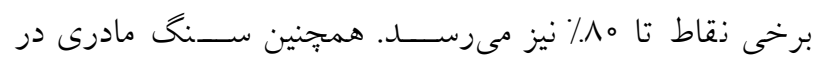

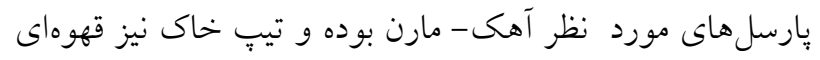

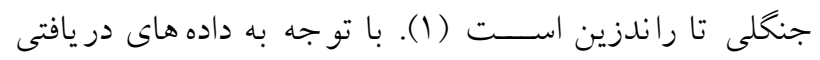

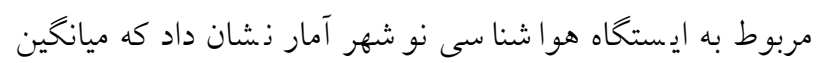

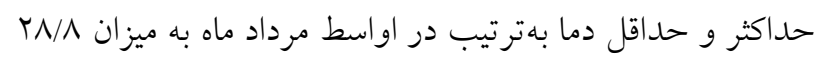

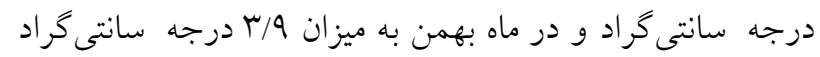

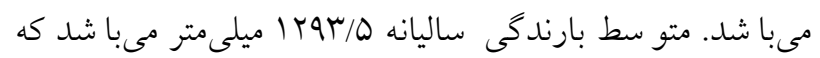

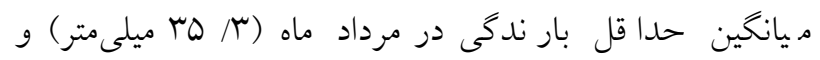

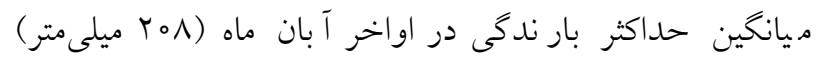

در بافتهاى گياهى بهطور مستقيم امكانيذير نيست ولى كل

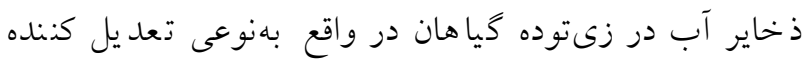

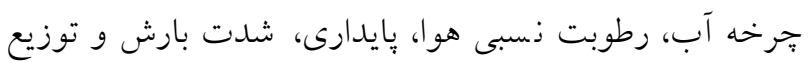

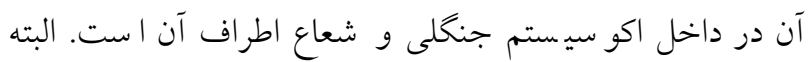

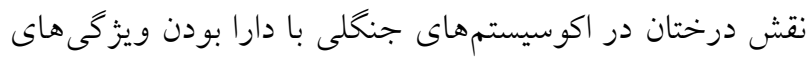

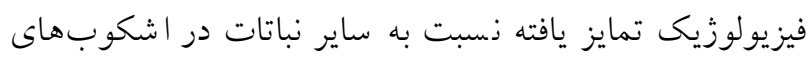
زيرين، ساختار كسترده تاج و تنههاى قطور در رابطه با استفاده از آب و ذخاير آن در بافتهاى مختلف بســـيار حائز اهميت اســت. در حقيقت بين ظرفيت وزنى آب و ميزان زىتوده

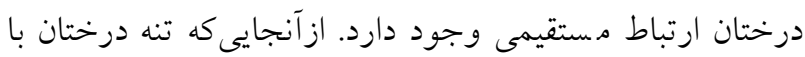

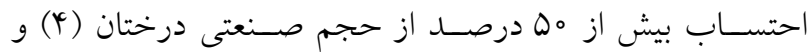
نزديك به مد در صد از وزن خشى (زىتوده هوايى) درختان را به خود اختصساص مىدهد (ه، 19 و هQT)، مىتواند حداكثر

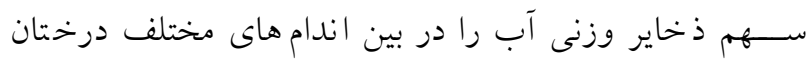

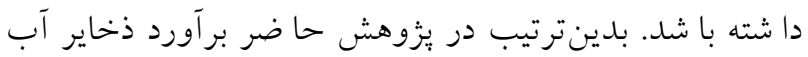
تنه درختان با حداكثر دقت در جنكل هاى طبيعى و آميخته

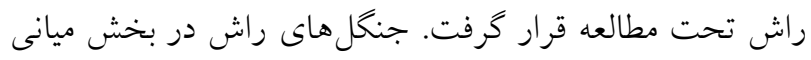

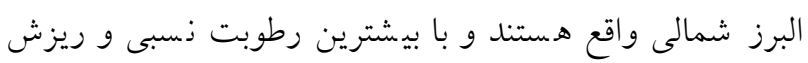

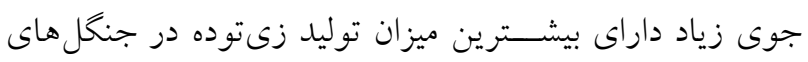

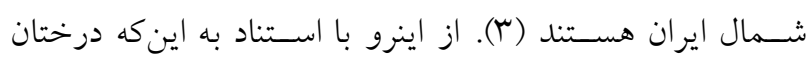

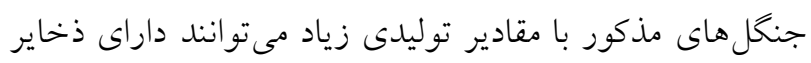

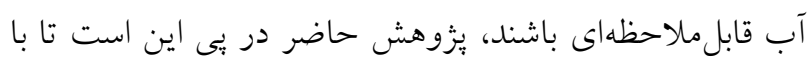

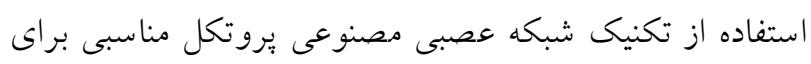

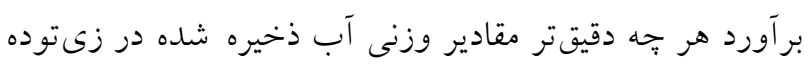

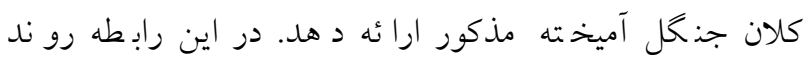

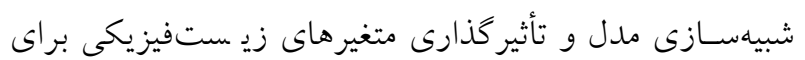

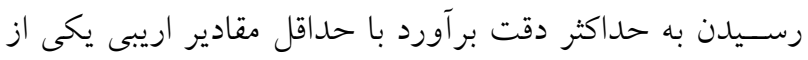

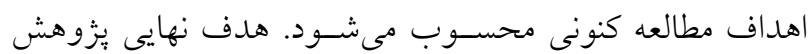
حا ضر اين ا ست تا با ا ستفاده از مدلهاى شبيه ساز باقابليت ديجيتالى در سيستمهاى رايانهاى دقت ارزيابى در روند اخلال

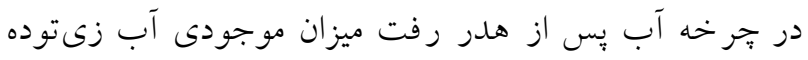

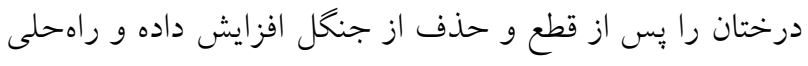


نمو نه هاى تكهبردارى شــــده، هر بخش از وزنت تر تنه هاى

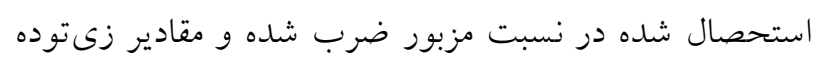

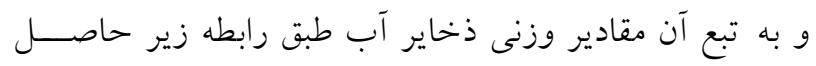

$\mathrm{W}_{\mathrm{H}_{\mathrm{r}} \mathrm{o}}=\sum_{\mathrm{i}=1}^{\mathrm{n}} \sum_{\mathrm{k}=1}^{\mathrm{n}}\left(\mathrm{w}_{\mathrm{k}}-\left(\frac{\mathrm{m}_{\mathrm{k}}}{\mathrm{M}_{\mathrm{k}}}\left(\mathrm{w}_{\mathrm{k}}\right)\right) \rightarrow\right.$ $\mathrm{M}_{\text {Bole }}-\mathrm{m}_{\text {Bole }}=\mathrm{W}_{\mathrm{H}_{\mathrm{r}} \mathrm{o}}$

در رابطه فوق، Wل كل ذخاير وزنى آب تنه درختان برحسب

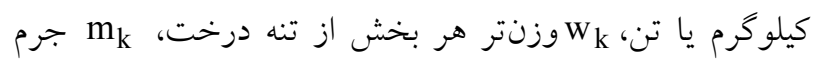
خشك هر بخش از قطعات نمونه برحسب كرم، M بخش از قطعات نمونه برحسب كرم، Mole

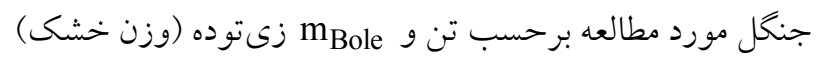

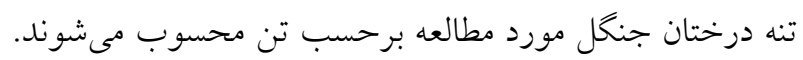

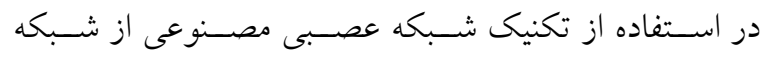
الكوريتم يسانتشار خطا استفاده شد. در اولين كام، كليه دادهها در قالب ماتريس متغيرهاى مسـتقل و متغير وابســهـ طبق رابطه

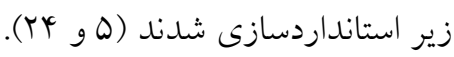

$\mathrm{X}_{\mathrm{n}}=\frac{\mathrm{x}_{\mathrm{i}}-\mathrm{x}_{\min }}{\mathrm{x}_{\max }-\mathrm{x}_{\min }}$

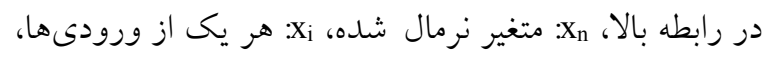

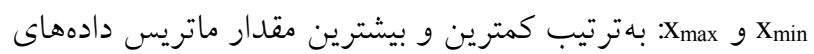

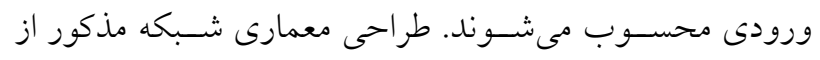

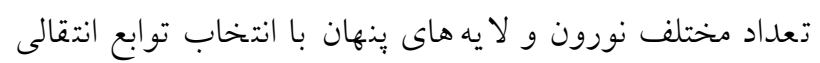

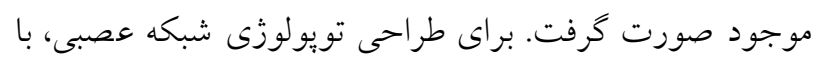

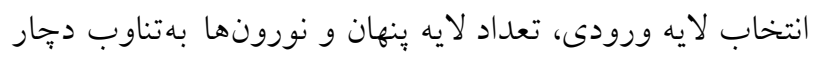
تغيير مىشــود مادامى كه بهدقت مورد نظر و انتخاب مدل بهينه

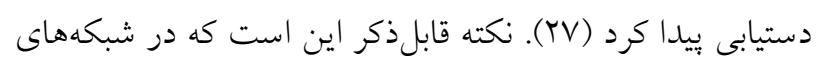

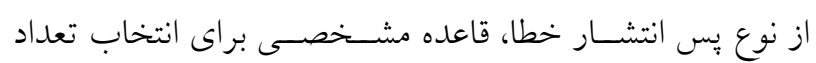

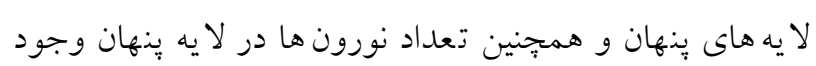

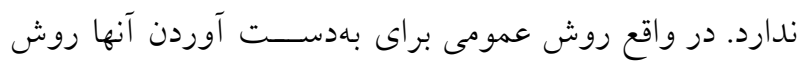

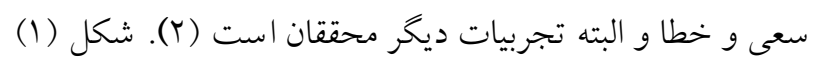

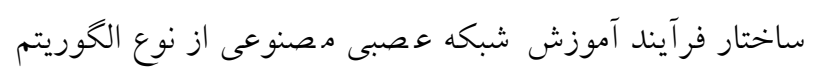
بس انتشار خطا را نشان مى دهد.

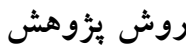

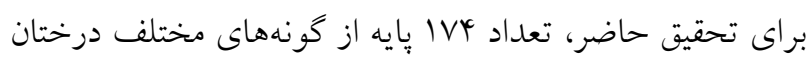

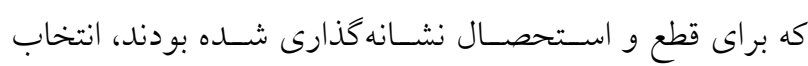

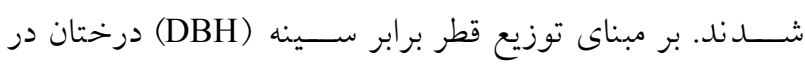

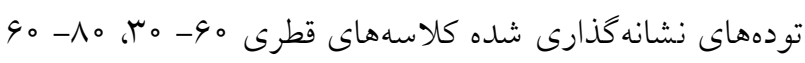
و بيش از •م سانتى متر براى انجام نمونهبردارى تخريبى انتخاب

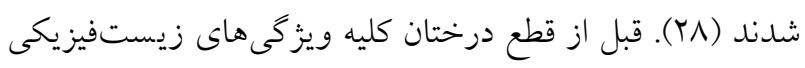
درختان ازجمله قطر برابر سـينه و ارتفاع تجارى يعنى ارتفاع تنه

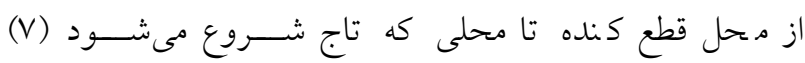

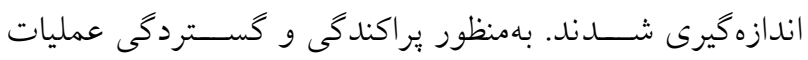

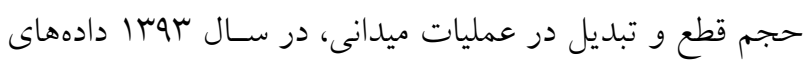
اندازهيرى شده با كليه دادههاى موجود در آرشيو اسناد دستخاه

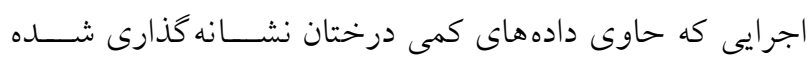
بودند، تطبيق داده شــــ در عرصسـه به هنخام تبديل تنه درختان

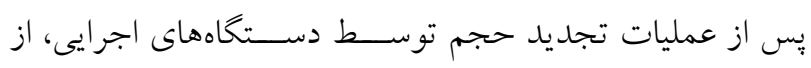

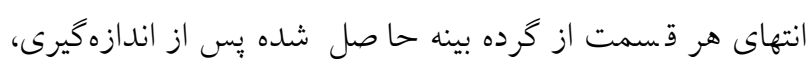

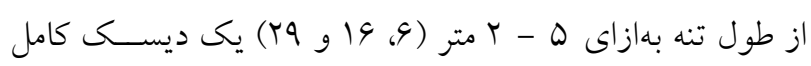

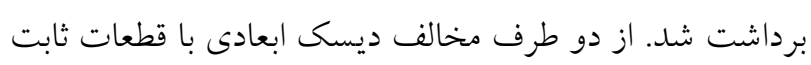

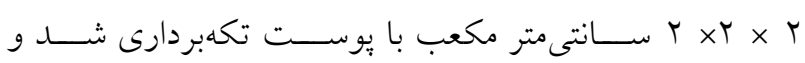

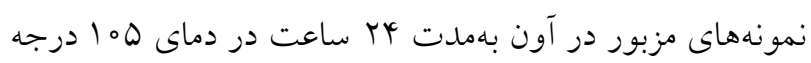

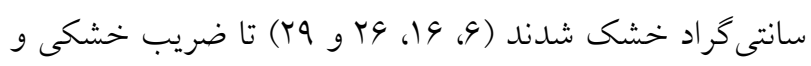
جإخالى ويزه هر نمونه محاسبه شود.

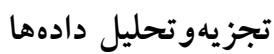

براى اندازهگيرى جخالى ويزه از رابطه زير استفاده شد (9) (1): $\rho=\frac{\mathrm{M}_{\mathrm{wk}}}{\mathrm{V}_{\mathrm{wk}}}$

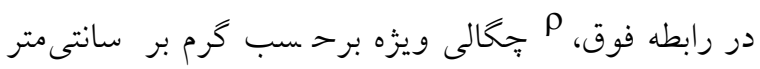

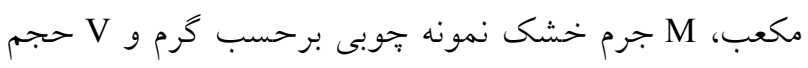

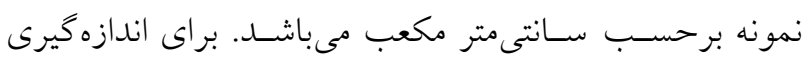

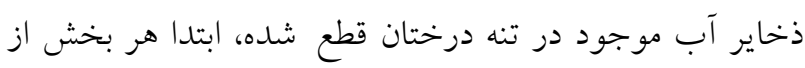

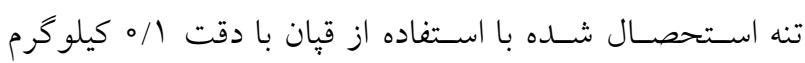

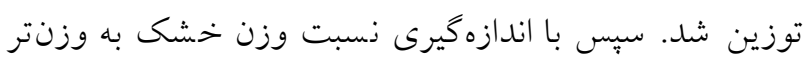




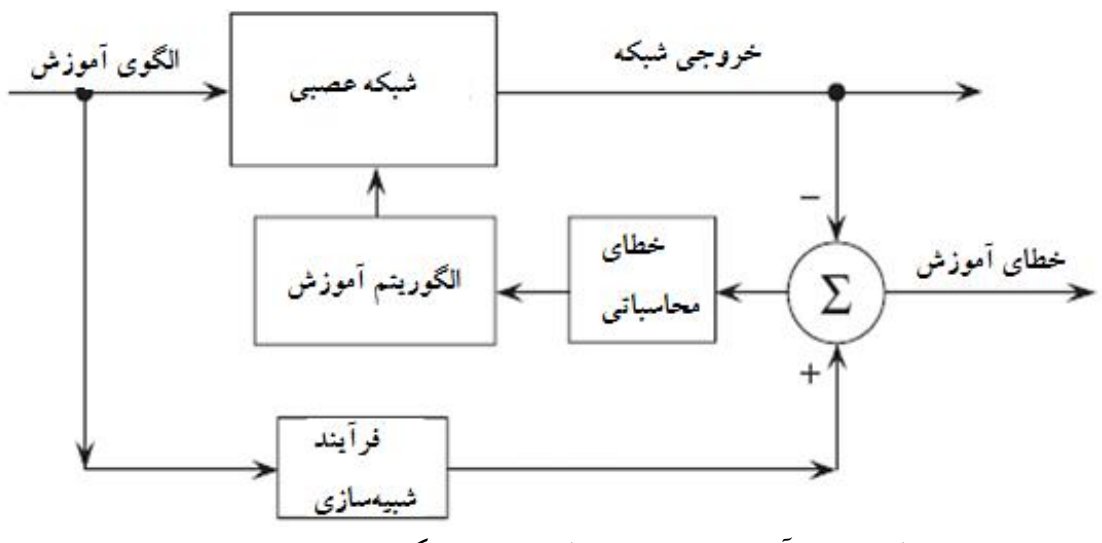

شكل 1. فرآيند شبيهسازى شبكه عصبى الخوريتم بسانتشار خطا

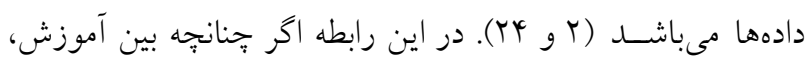

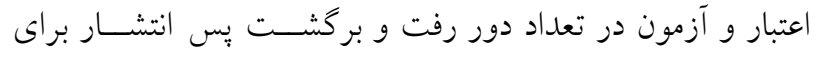

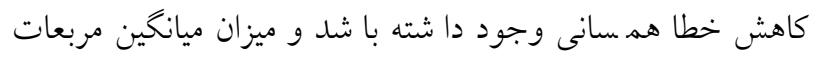

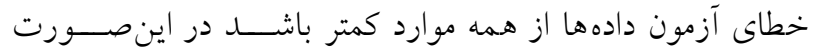
خروجى تعريف شده با تويولوزى طراحى شده در شبكه از اعتبار

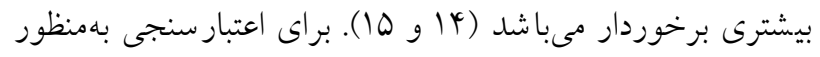

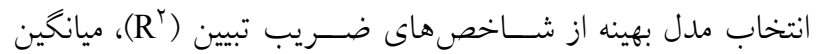

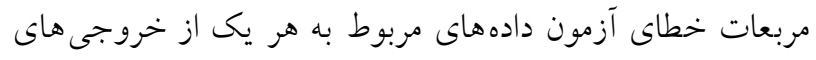

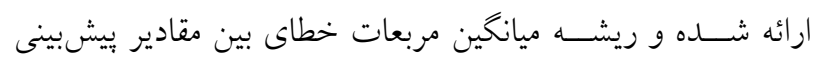

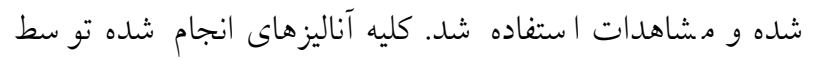

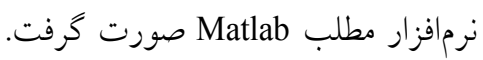

\section{نتايج تحقيق}

جدول (1) نتايج تحليلى شبيهسازى ذخاير آب با استفاده از يك لإئ

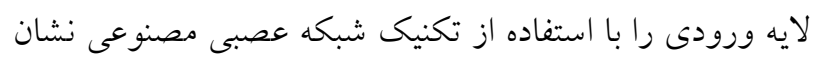

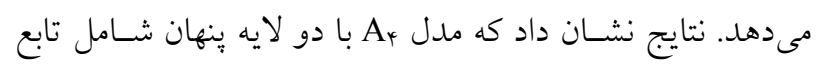

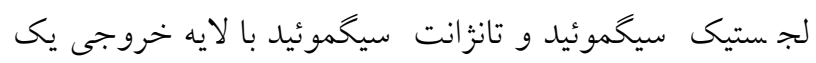

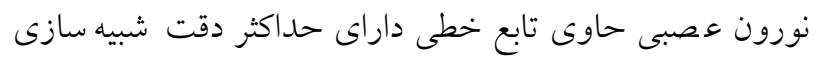

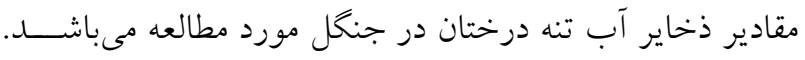

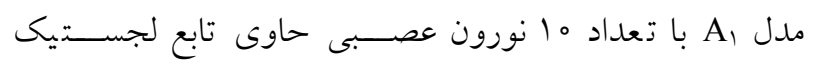

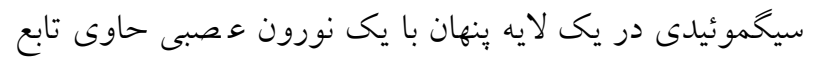

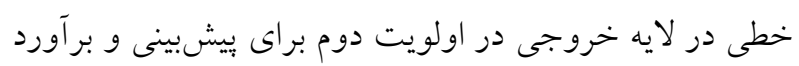

براى انجام عمليات شبيه سازى از عوامل تو صيفى قطر برابر

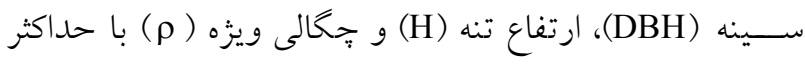

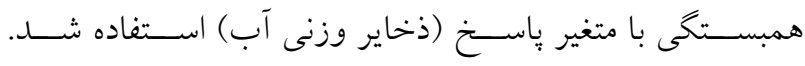

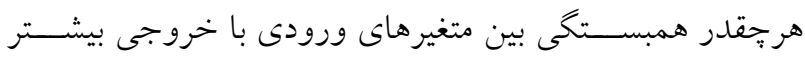

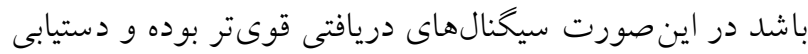

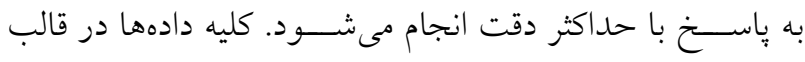

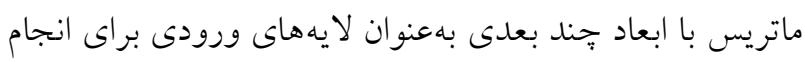

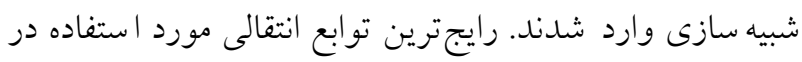

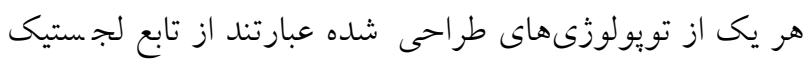

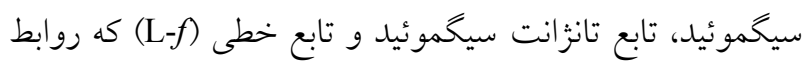
آنها بهترتيب در زير عنوان شده است:

$\mathrm{Y}=\frac{1}{1+\exp \left(-\mathrm{x}_{\mathrm{i}}\right)}-(\log -$ sigmoid $)$

$\mathrm{Y}=\frac{r}{\left[1+\exp -\left(r \mathrm{x}_{\mathrm{i}}\right)\right]}-($ Tan - sigmoid $)$

$\operatorname{Purelin}(\mathrm{n})=\mathrm{n} \rightarrow$ Linear(f)

در شبيه سازى شبكه عصبى با ا ستفاده از توابع فوق، معمولاً

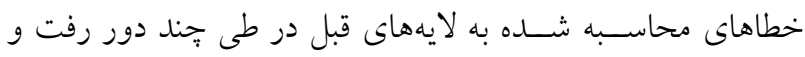

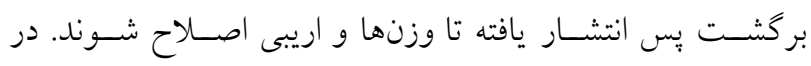

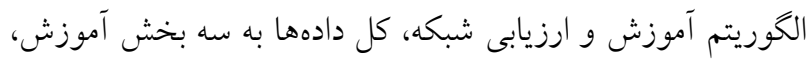

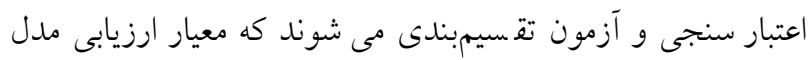

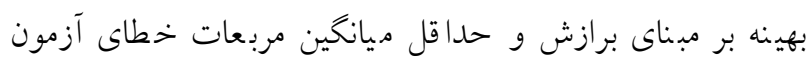


جدول ا. نتايج تحليلى شبيه سازى ذخاير آب با استفاده از يك لايه ورودى قطر برابر سينه

\begin{tabular}{|c|c|c|c|c|c|c|c|}
\hline كد & ساختار ورودى شبكه & تويولوزى توابع انتقالى شبكه عصبى & تعداد نورون & $\begin{array}{l}\frac{\pi}{8} \\
8 \\
0 \\
0\end{array}$ & $\mathrm{R}^{r}$ & $\mathrm{MSE}_{\text {test }}$ & RMSE \\
\hline $\mathrm{A}_{1}$ & $\mathrm{DBH} \rightarrow \mathrm{W}_{\mathrm{H}_{\curlyvee} \mathrm{O}}$ & Logsig $\rightarrow$ Purelin & 10 & ro &.$/ 900$ & $0 / 0011$ & TIS/TQ \\
\hline $\mathrm{A}_{r}$ & $\mathrm{DBH} \rightarrow \mathrm{W}_{\mathrm{H}_{r} \mathrm{O}}$ & Tansig $\rightarrow$ Purelin & 10 & $\wedge$ & o/OTY & $\circ / 0 \mid V D$ & TYT/OG \\
\hline $\mathrm{A}_{r}$ & $\mathrm{DBH} \rightarrow \mathrm{W}_{\mathrm{H}_{r} \mathrm{O}}$ & Tansig $\rightarrow$ Logsig $\rightarrow$ Purelin & $r \Delta-r_{0}$ & 9 & $\circ / 4 \circ \Delta$ &.$/ 014$ & rMV/A \\
\hline $\mathrm{A}_{+}$ & $\mathrm{DBH} \rightarrow \mathrm{W}_{\mathrm{H}_{r} \mathrm{O}}$ & Logsig $\rightarrow$ Tansig $\rightarrow$ Purelin & $r \Delta-r_{0}$ & 11 &.$/ 990$ & $\circ / 0099$ & $r I 1 / r V$ \\
\hline $\mathrm{A}_{\diamond}$ & $\mathrm{DBH} \rightarrow \mathrm{W}_{\mathrm{H}_{r} \mathrm{O}}$ & Tansig $\rightarrow$ Tansig $\rightarrow$ Purelin & $10-0$ & ro & $\circ / \wedge \varphi$ & $\circ / 01 \mu_{0}$ & TYN/99 \\
\hline $\mathrm{A}_{\varphi}$ & $\mathrm{DBH} \rightarrow \mathrm{W}_{\mathrm{H}_{r} \mathrm{O}}$ & Logsig $\rightarrow$ Logsig $\rightarrow$ Purelin & $r \Delta-r_{0}$ & $\wedge$ & $\circ / \Delta \Delta r$ & 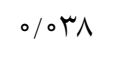 & rys/01 \\
\hline $\mathrm{A}_{\vee}$ & $\mathrm{DBH} \rightarrow \mathrm{W}_{\mathrm{H}_{r} \mathrm{O}}$ & Tansig $\rightarrow$ Logsig $\rightarrow$ Tansig $\rightarrow$ Purelin & $1 \circ-\infty-\omega$ & 11 & $\circ N T \Delta$ & O०Yr & rTH/NY \\
\hline $\mathrm{A}_{\wedge}$ & $\mathrm{DBH} \rightarrow \mathrm{W}_{\mathrm{H}_{r} \mathrm{O}}$ & Tansig $\rightarrow$ Tansig $\rightarrow$ Tansig $\rightarrow$ Purelin & $r_{0}-r Q-r Q$ & ir & $0 /$ TrV & $0 / 0109$ & $r 90 / 4 r$ \\
\hline $\mathrm{A}_{4}$ & $\mathrm{DBH} \rightarrow \mathrm{W}_{\mathrm{H}_{r} \mathrm{O}}$ & Tansig $\rightarrow$ Logsig & rQ & Vq & $\circ / \circ r^{2}$ &.$/ 111$ & 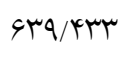 \\
\hline$A_{1}$ & $\mathrm{DBH} \rightarrow \mathrm{W}_{\mathrm{H}_{r} \mathrm{o}}$ & Tansig $\rightarrow$ Tansig & 10 & Q9 & $\circ / N 19$ & $\circ / 014 \wedge$ & $r r_{0} / \circ \Lambda$ \\
\hline$A_{11}$ & $\mathrm{DBH} \rightarrow \mathrm{W}_{\mathrm{H}_{r} \mathrm{o}}$ & Logsig $\rightarrow$ Tansig $\rightarrow$ Tansig & $r \Delta-r_{0}$ & 14 & $\circ / \Delta Y$ &.$/ M 1$ & $V I T / Y Y$ \\
\hline$A_{1 r}$ & $\mathrm{DBH} \rightarrow \mathrm{W}_{\mathrm{H}_{r} \mathrm{O}}$ & Logsig $\rightarrow$ Logsig $\rightarrow$ Logsig & $r Q-r_{0}$ & 11 & $0 / 049$ &.$/ \mathrm{kr}$ & VIV/Ir \\
\hline
\end{tabular}

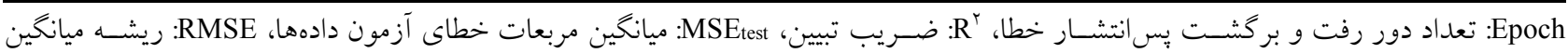
مربعات خطاى بين مشاهدات و مقادير شبيهسازى شده

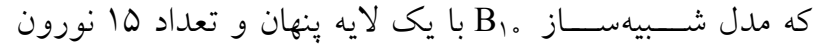
عصبى حاوى تابع تانزانت سيخموئيدى بهعنوان بهترين بيشيشو داراى حداكثر دقت برآوردى و قطعيت محاســباتى محســوبـ

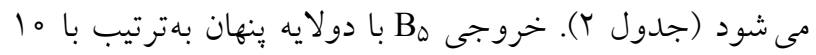

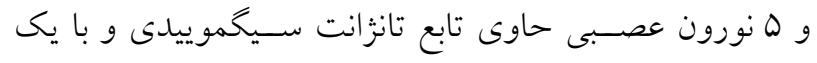
نورون حاوى تابع خطى در لا يه خروجى به عنوان بهترين بيشخو در اولويت دوم معرفى شد (جدول Y). مطابق جدول rل، طراحى هاى مختلف تويولوزى با اسـتفاده از ســه لايه ورودى سئ قطر برابر سينه، ارتفاع تنه و جگالى ويزه در شبكه عصبى مورد ا ستفاده تأثير جندانى در افزايش دقت شبيه سازى متغير پيا سخ مورد مطالعه (موجودى وزنى آب تنه درختان جنگل آميخته راش) نداشت. شــكل (†) و (ه) بهترتيب برازش بين مشــاهدات و مقادير

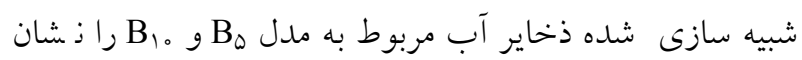
مى دهد. با توجه به برازش نشان داده شده در شكل ه و مقادير
ذخاير آب با حداكثر قطعيت در جنگل مورد مطالعه را دارد. با افزايش تعداد لايههاى ينهان و تعداد مختلف نورونهاى عصـبى حاوى توابع مختلف در هر لايه دقت قابلملاحظهاى مشـــاهده

اشـكال زير برازش بين مشـاهدات اندازهذيرى شــده ذخاير آب در تنه درختان جنگل آميخته راش و مقادير شبيهسازى شده ذخاير آب با ا ستفاده از تكنيك شبكه عصبى مصنوعى را ذشان مى دهد. همانطور كه در شـكل (T) مشـاهده مىشـود ضـريب تبيين حاصل از برازش بهد ست آمله بين مشاهدات و خروجى

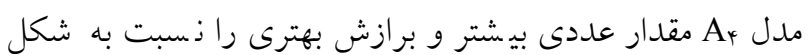

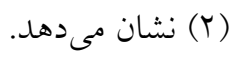

در روند شـبيهسـازى ذخاير آب در جنخل مورد مطالعه از عوامل توصــيفى ارتفاع تنه و جّالى ويزّه علاوه بر قطر برابر سـينه نيز بهعنوان لايههاى ورودىى براى افزايش دقت برآورد و بيشبينى متغير وِا سخ ا ستفاده شد (جدول Y). نتايج ذشان داد 


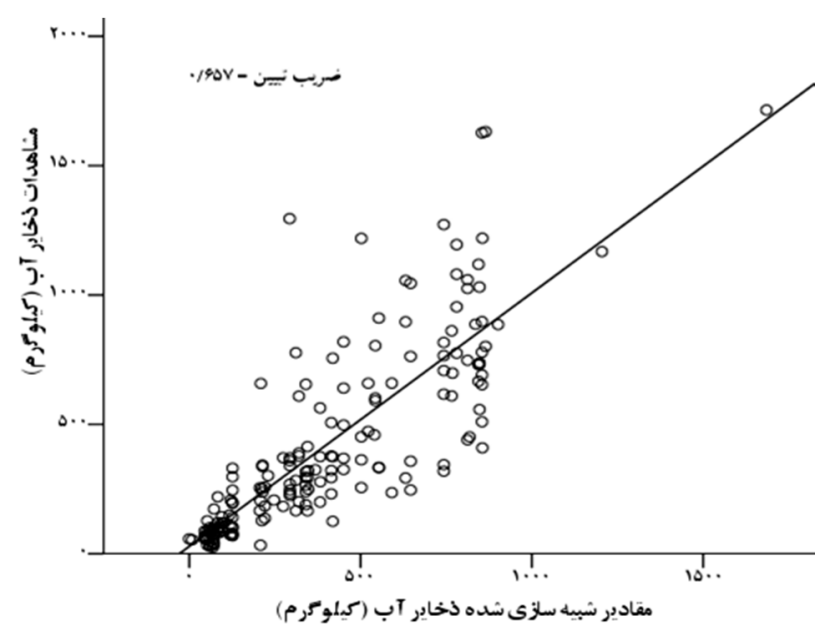

شكل r. برازش بين مشاهدات ذخاير آب و مقادير شبيهازى شده

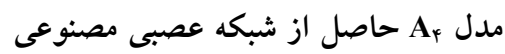

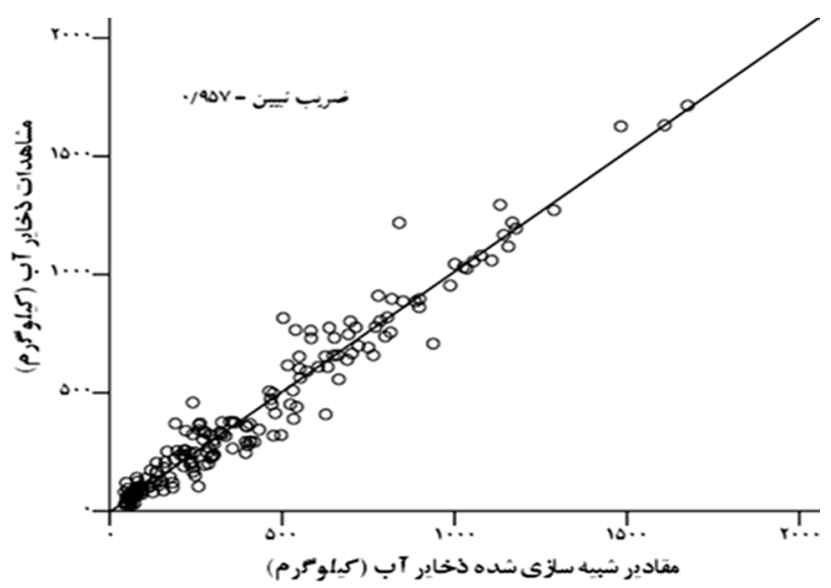

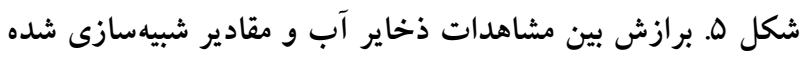
مدل .B حاصل از شبكه عصبى مصنوعى

r، شــكل ه). نتايج زيادى نشـــان دادند كه مقادير زىتوده تنه درختان همبستكى زيادى با قطر برابر سينه دارد (ه، م ا و צY). هر جقدر ميزان توليد خالص ساليانه زيادتر باشد و ازآنجايىكه درختان براى توليد هر جهه بيشتر زىتوده به ميزان آب بيشترى ذياز دار ند از اين لحاظ در زىتوده كلان كه داراى (WUE) مقادير وزنى زيادى هســتند، ذخاير آب بيشـــرى وجود دارد. بههمين دليل در نتايج شـبيهسـازى بهينه بزوهش حاضـر، قطر برابر سـينه تقريباً هو درصــ از تغييرات واريانس را در برازش مربوط به آزمون دادهها توجيه كرده است. مطالعات زيادى نشان

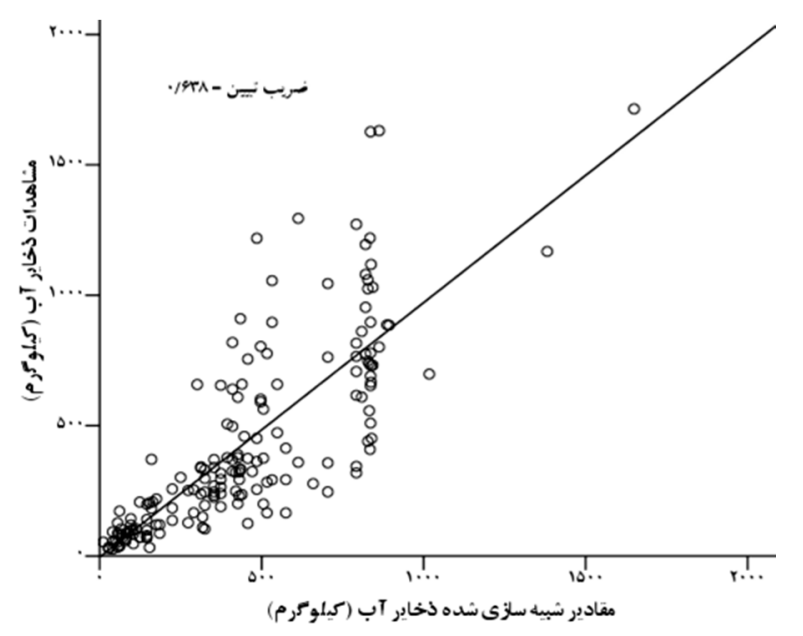

شكل r. برازش بين مشاهدات ذخاير آب و مقادير شبيهازى شده مدل A حاصل از شبكه عصبى مصنوعى

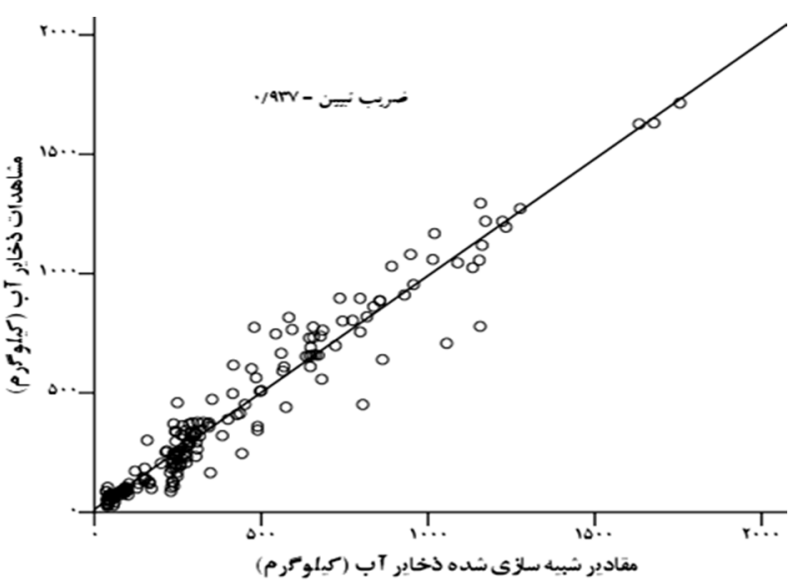
شكل †ل. برازش بين مشاهدات ذخاير آب و مقادير شبيهسازى شده مدل B حاصل از شبكه عصبى مصنوعى

عددى ضــر يب تبيين مىتوان با قطعيت اذعان كرد كه مدل شــبيهســاز نهايى معرفى شــــه مى تواند بهعنوان خروجى بهينه حاصل از شبيهازى ذخاير آب در يزوهش حاضر معرفى شود. نتايج يزوهش حاضــر نشـان داد كه لايههاى ورودىى قطر برابر

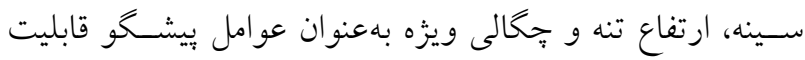
زيادى براى ييشبينى صسحيح مقادير وزنى آب ذخيره شـده تنه در درختان جنگل آميخته راش تحت مطالعه را دارند (جدول 
جدول r. نتايج تحليلى شبيه سازى ذخاير آب با استفاده از سه لايه ورودى قطر برابر سينه، ارتفاع تنه و جگالى ويزٌه

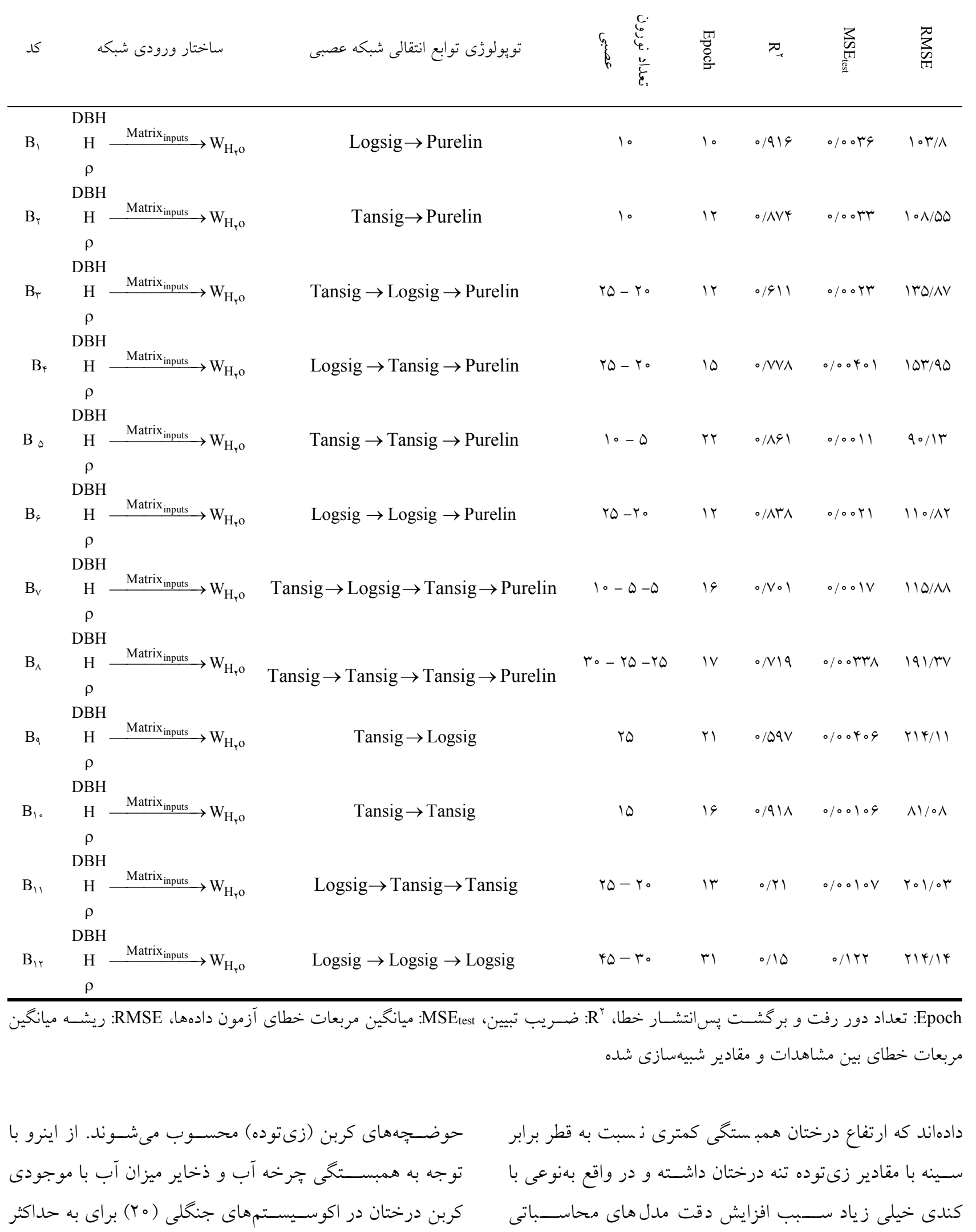


بودند. ولى مطالعات مختلفى بر اين نكته تأكيد دارند كه اولويت

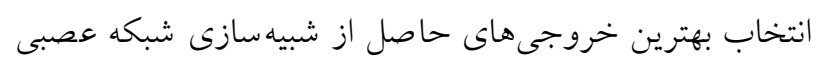
مـ صنوعى بر مبناى ري شه ميانخين مربعات خطاى آزمون دادهها،

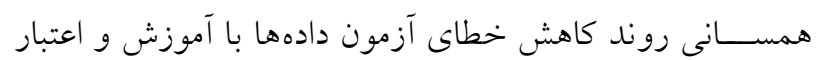
دادهها، ريشــه ميانخين مربعات خطاى بين مشـــاهدات (مقادير و اقعى) و مقادير تخمينى مىباشد (ه، سا، ها و 19). از اينرو در

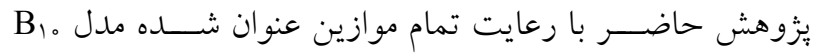

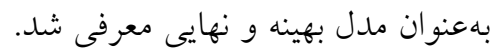

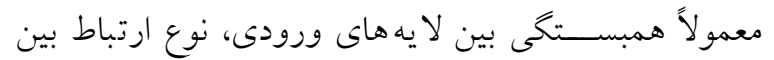
لايههاى ورودى و خروجى، تقارن و يا عدم تقارن بين دادهها در شـبيهسـازى شـبكههاى عصـبى مصـنوعى برخلاف كليه تحليل هاى محاسباتى (مانند مدلسازى ركرسيون) هيج تأثيرى

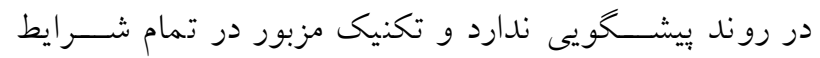

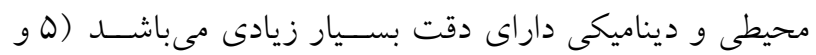
rا). كيوليبالى و همكاران عنوان كردند كه تكنيك اسـتفاده از

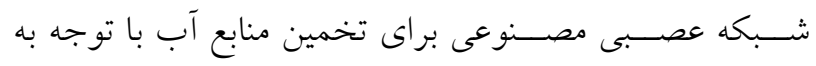

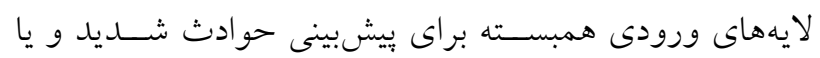

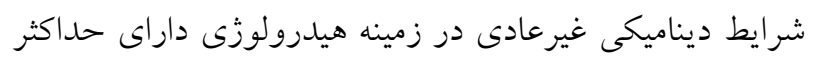

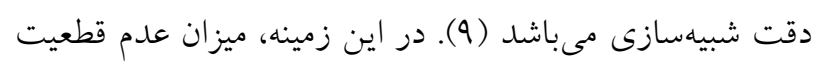

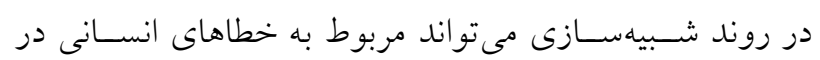

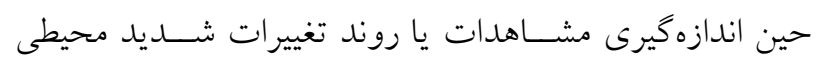

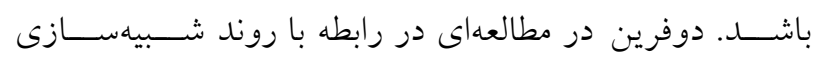

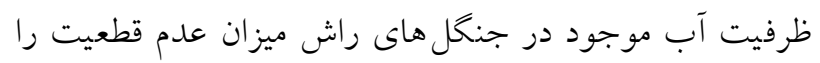

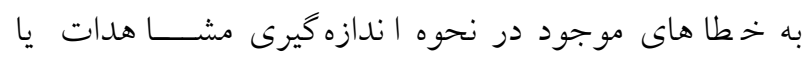

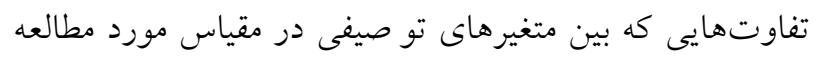

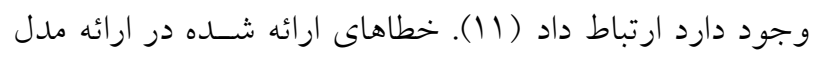
بهينه در تحقيق حاضـر نيز مىتواند منوط به موارد ذكر شــده

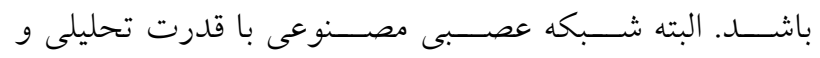

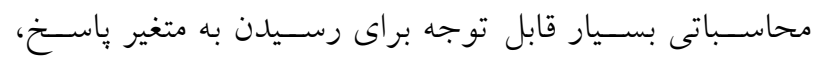

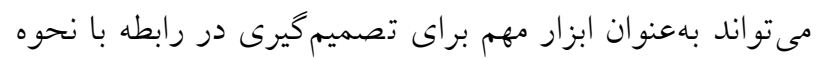

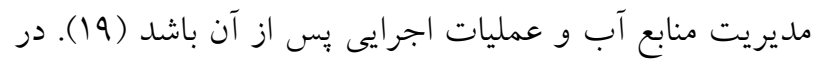

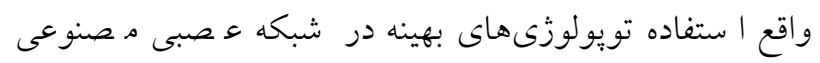

رســـاندن دقت برآوردى ذخاير آب، ارتفاع درختان بههمراه

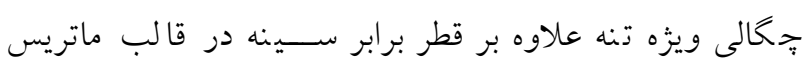
دادههاى ورودى براى شبيه سازى ا ستفاده شد. جّكالى درختان

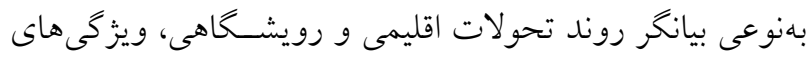

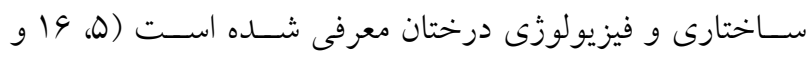

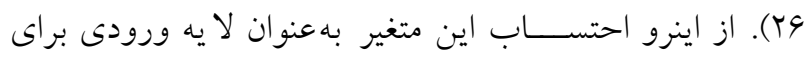

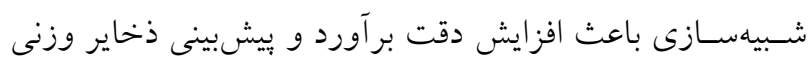

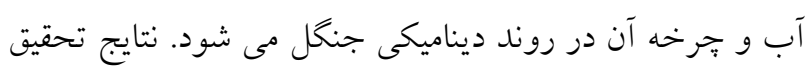

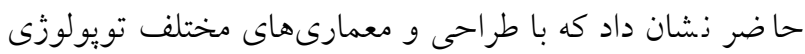
B! شبكه عصبى مورد مطالعه در يزوهش حاضر مدل شبيهساز

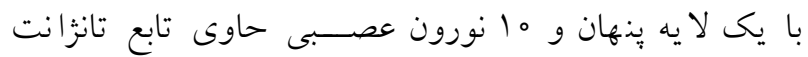

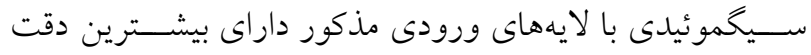

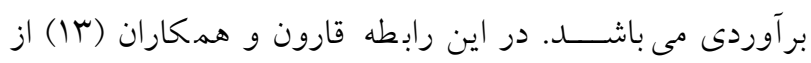
مقادير بارندگى و شاخص تفا ضل نرمال شده گياهان (NDVI)

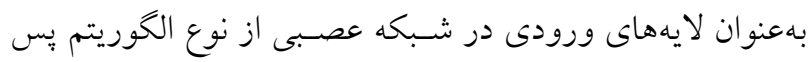

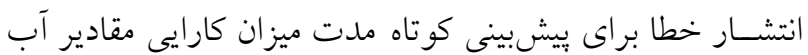

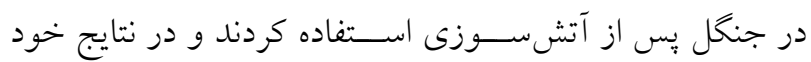
نشان دادند ضريب همب ستخى حا صل از برازش آزمون دادهها بو R = م و خروجى بهينه بهدســت آمده داراى حداقل

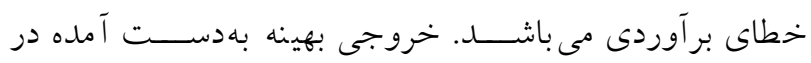

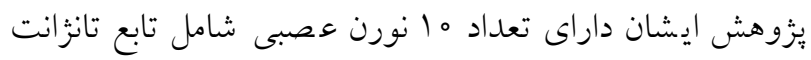

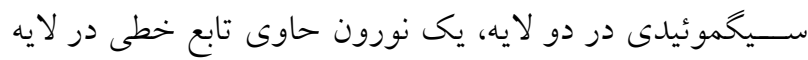
خروجى و سه دور بسامد كاهش انتشار خطا (Epoch) مىباشد.

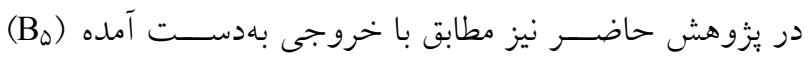

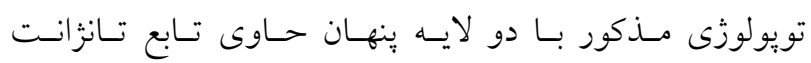

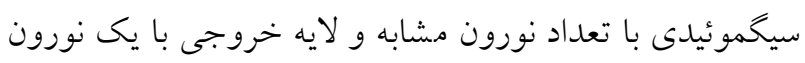

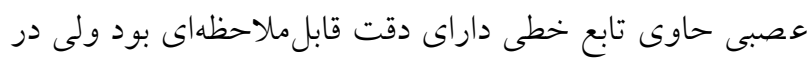
ادامه معمارى براى د ستيابى به بهترين مدل شبيه ساز با حداكثر

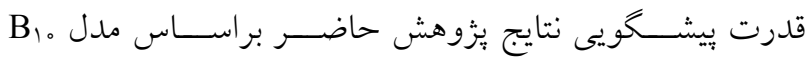

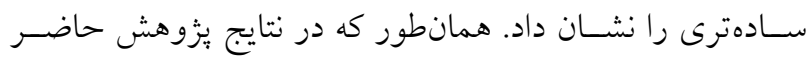
نشـان داده شـد، برخى از مدلهاى غير بهينه كه در دسـتهبندى

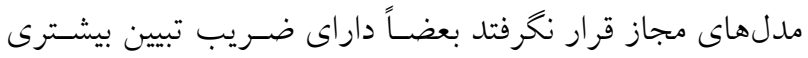


نمود. البته واحدى (YN) در رابطه با ارائه مدل هاى شــبكه

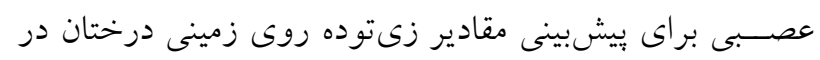

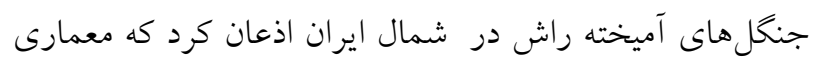

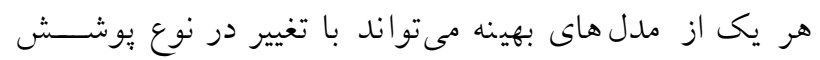

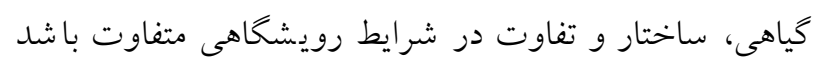

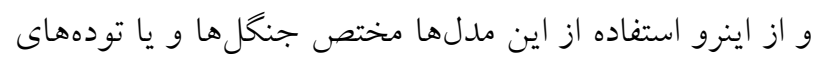
درختانى است كه داراى شرايط روي شخاهى مـ شابهى با شند.

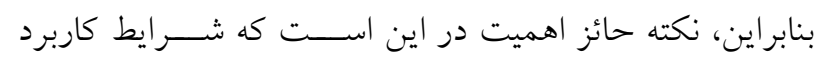

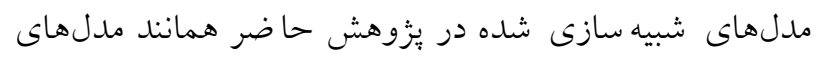

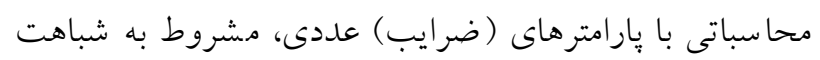

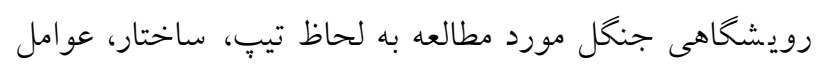

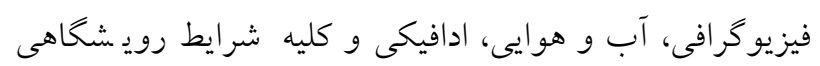

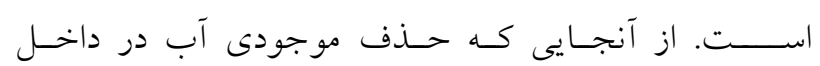

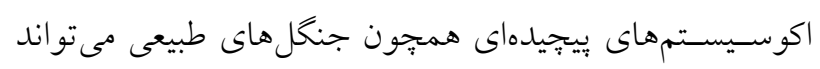

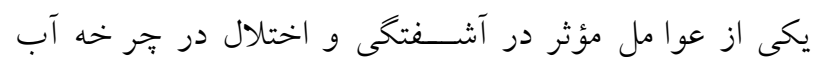

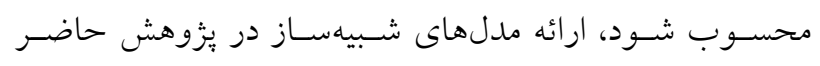

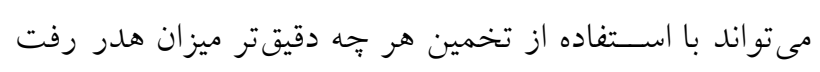

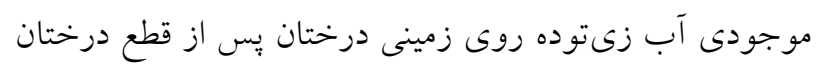

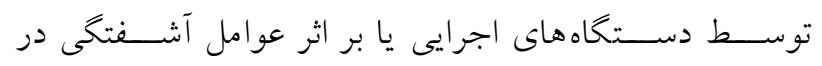

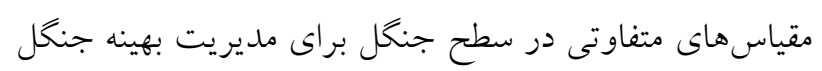

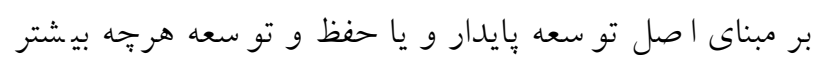

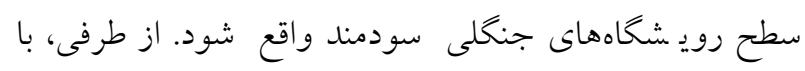

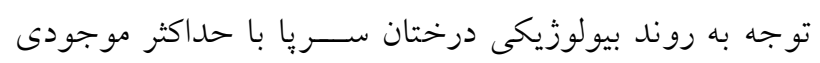

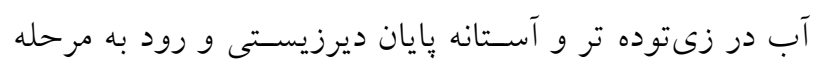

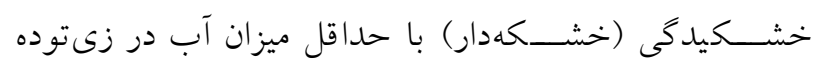

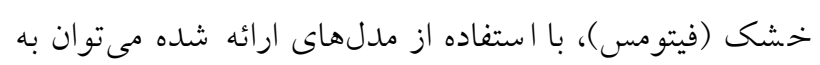

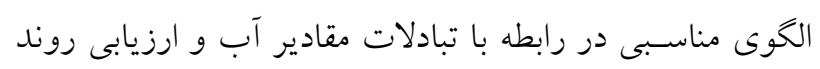

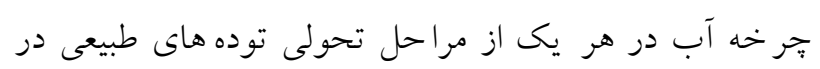
سطوح وسيعى از رويشگاه جنگل برداخت.
براى مديريت بهينه منابع آب باعث كاهش هزينه هاى مالى و

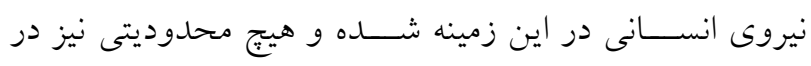
رابطه با اسـتفاده از خروجى هاى بهينه براى تخمين نزديك بـ به دينه

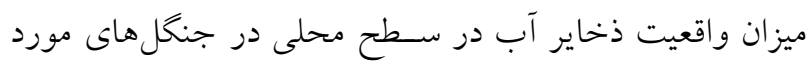

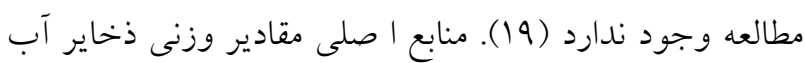

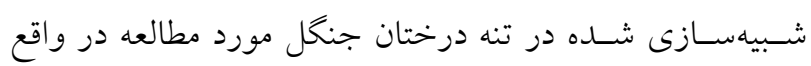

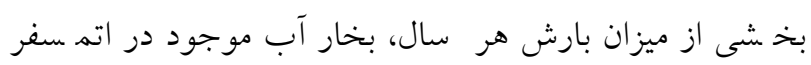

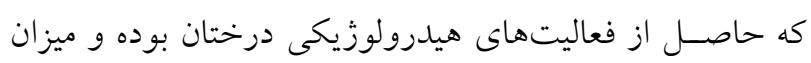

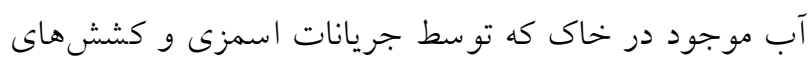

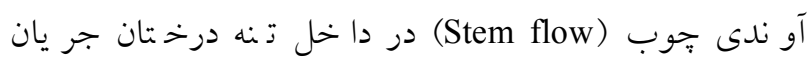

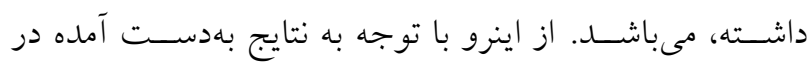

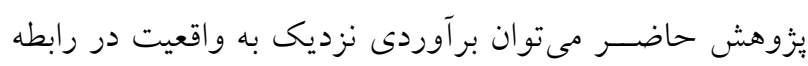

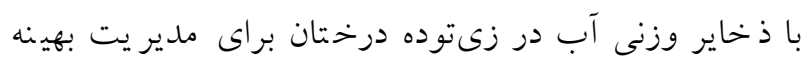

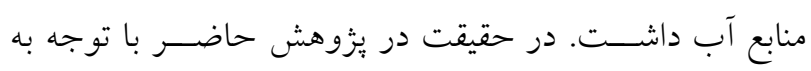

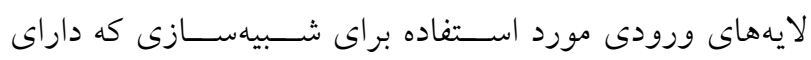

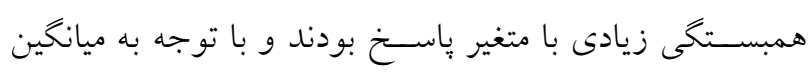

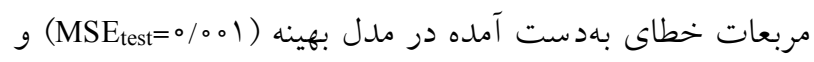

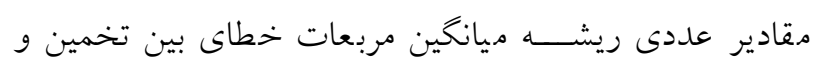

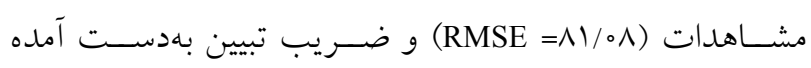
( $\mathrm{R}^{r}=$ = $\left./ 9 \Delta V\right)$

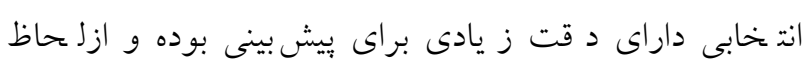

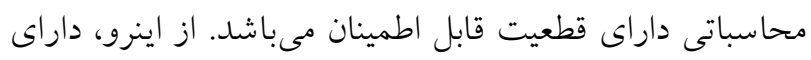

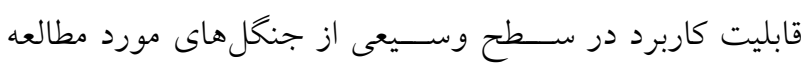

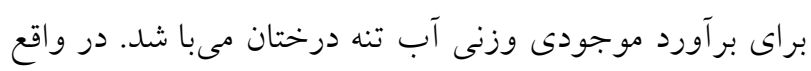

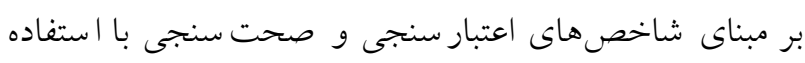

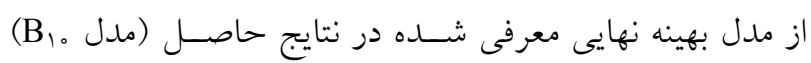

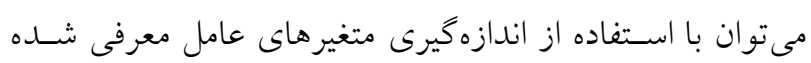
موجودى آب زى متوده درختان جنگل آميخته راش در رويشخاه

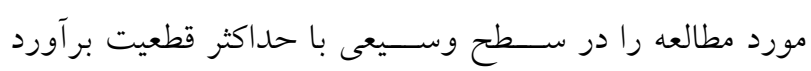

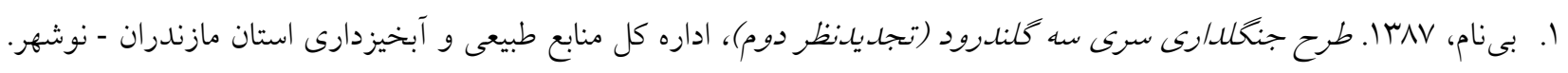




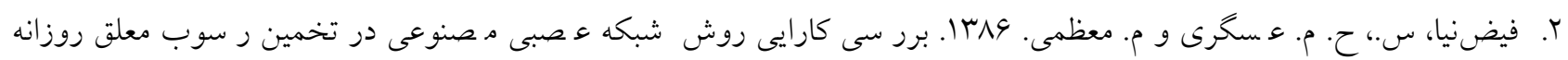

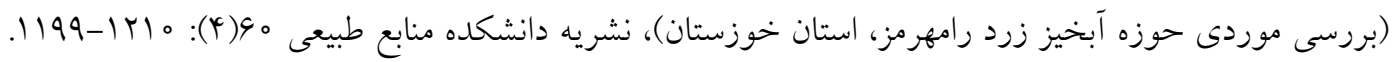

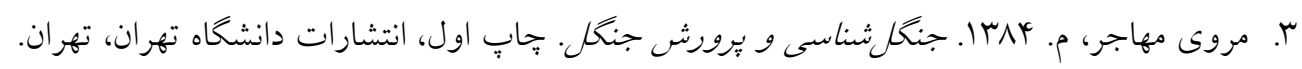

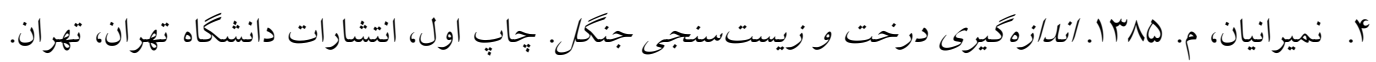

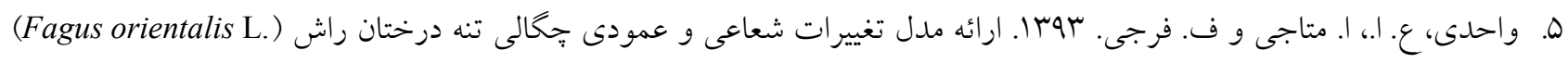

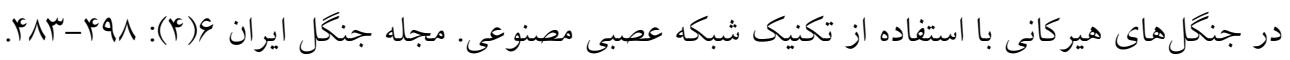

6. Aboal, R. J., J. Ramon Arevalo and A. Fernandez. 2005. Allometric relationships of different tree species and stand above ground biomass in the Gomera laurel forest (Canary Islands). Flora. 200:264-274.

7. Basuki, T. M., P. E. Van Laake, A. K. Skidmore and Y. A. Hussin. 2009. Allometric equations for estimating the above-ground biomass in tropical lowland Dipterocarp forests, For. Ecol. Manage. 257: 1684-1694.

8. Bonan, G. B., S. Levis, S. Sitch, M. Vertenstein and K. W. Oleson. 2003. A dynamic global vegetation model for use with climate models concepts and description of simulated vegetation dynamics, Glob. Change. Bio. 9: 1543-1566.

9. Coulibaly, P., B. Bobee and F. Antcil. 2001. Improving extreme hydrologic eventsforecasting using a new criterion for artificial neural network selection, Hydrol. Process 15: 1533-1536.

10. Djomo, A. N., I. Adamou, S. Joachim and G. Gode. 2010. Allometric equations for biomass estimations in Cameroon and pan moist tropical equations including biomass data from Africa, For. Ecol. Manage. 260: 1873-1885.

11. Dufrene E., H. Davi C. Francois G. L. Maire, V. L. Dantec and A. Granier. 2005. Modelling carbon and water cycles in a beech forest Part I: Model description and uncertainty analysis on modelled NEE, Ecol. Model. 185: 407-436.

12. Frolking, S., N. Roulet, T. R. Moore, P. J. H. Richard, M. Lavoie and S. D. Muller. 2001. Modeling northern peatland decomposition and peat accumulation, Ecosystems. 4: 479-498.

13. Gharun M., M. Azmi and M. A. Adams. 2015. Short-Term Forecasting of Water Yield from Forested Catchments after Bushfire: A Case Study from Southeast Australia, Water 7: 599-614.

14. Hagan, M. T., H. B. Dcmuth and M. Beale. 1996. Neural Network Design, PWS Publishing Co, United States of America.

15. Haykin, S. 2008. Neural Networks and learning machines, Third edition, Pearson Education, 906 pp.

16. Henry, M., A. Besnard, W. A. Asante, J. Eshun, S. Adu-Bredu, R. Valentini, M. Bernoux and L. Saint-André. 2010. Wood density, phytomass variations within and among trees, and allometric equations in a tropical rainforest of Africa, For. Ecol. Manage. 260: 1375-1388.

17. Hetherington A. M. and F. I. Woodward. 2003. The role of stomata in sensing and driving environmental change, Nature. 424: 901-908.

18. Holtum, J. A. M. and K. Winter. 2010. Elevated $\left[\mathrm{CO}_{2}\right]$ and forest vegetation: more a water issue than a carbon issue?, Func. Plant. Bio. 37: 694-702.

19. Iliadis L. S. and F. Maris. 2007. An Artificial Neural Network model for mountainous water-resources management: The case of Cyprus mountainous watersheds, Environmental Modelling \& Software 22: 1066-1072.

20. Ju, W., J. M. Chen, T. A. Black, A. G. Barr, H. Maccaughey and N. T. Roulet. 2006. Hydrological effects on carbon cycles of Canada's forests and wetlands, Tellus 58: 16-30.

21. Ketterings, Q. M., R. Coe, M. V. Noordwijk, Y. Ambagau and C. A. Palm. 2001. Reducing uncertainty in the use of allometric biomass equations for predicting abone-ground tree biomass in mixed secondary forests, For. Ecol. Manage. 146: 199-209.

22. Kljun, N., T. A. Black, T. J. Griffis, A. G. Barr, D. Gaumont-Guay, K. Morgenstern, J. H. McCaughey and Z. Nesic 2004. Net carbon exchange of three boreal forests during a drought. In: Proceedings of the $26^{\text {th }}$ Conference on Agricultural and Forest Meteorology, August 23-27, Vancouver, BC, Canada. mericanMeteorology Society, Boston, MA, P4,5, 4 pp.

23. Mund, M., E. Kummetz, M. Hein, G. A. Bauer and E. D. Schulze. 2002. Growth and carbon stocks of a spruce forest chronosequence in central Europe, For. Ecol. Manage. 171: 275-296.

24. Naghdi, R. and I. Ghajar. 2012. Application of Artificial Neural Network in the Modeling of Skidding Time Prediction, Adv. Mater. Res. 403: 3538-3543.

25. Navar, J. 2009. Allometric equations for tree species and carbon stocks for forests of northwestern Mexico, For. Ecol. Manage. 257: 427-434.

26. Ribeiro, C. S., L. Fehrmann, C. Pedro Boechat Soares, L. Antônio Gonçalves Jacovine, C. Kleinn and R. de Oliveira Gaspar. 2011. Above- and belowground biomass in a Brazilian Cerrado, For. Ecol. Manage. 262: 491-499. 
27. Tiryaki, S. and A. Aydin. 2014. An artificial neural network model for predicting compression strength of heat treated woods and comparison with a multiple linear regression model, Cons. Build. Mater. 62: 102-108.

28. Vahedi, A. A. 2016. Artificial neural network application in comparison with modeling allometric equations for predicting above-ground biomass in the Hyrcanian mixed-beech forests of Iran, Biomass and Bioenergy 88: 66- 76.

29. Zhu, B., X. Wang, W. Fang, S. Piao, H. Shen, S. Zhao and C. Peng. 2010. Altitudinal changes in carbon storage of temperate forests on Mt Changbai, Northeast China, J. Plant. Res. 123: 439-452. 


\title{
Simulating Water Resources within Biomass Structure of Trees Storey in the Natural and Mixed-Beech Forests in North of Iran using Artificial Neural Network
}

\author{
A. A. Vahedi ${ }^{*}$ \\ (Received: Nov. 1-2015 ; Accepted: June 6-2016) \\ DOI: 10.18869 /acadpub.jstnar.20.78.53
}

\begin{abstract}
Due to water shortage in country, more accurate estimate of water reserve can be one of the most important guidelines on the optimal management of water resource and cycle for development of water productivity efficiency. Therefore, using artificial neural network techniques the water supply of 174 fallen trees from different species was simulated. From any part of each bole, components of constant volume were extracted and placed in $105^{\circ} \mathrm{C}$ to be oven-dried to measure specific drought index and wood density. Three input layers of diameter at breast height, height and specific wood density were used to simulate the response variable. The method of trial and test were used for neural network topology architecture. The results showed that the use of only diameter as input layer based on the validation indices explained $65 \%$ of variance of test of data. Using the three layers in the neural network, optimized output including function of Tan-sigmoid in the designed architecture with the number of 15 neurons demonstrated the highest accuracy $\left(\mathrm{R}^{2}=0 / 92, \mathrm{MSE}=0 / 001, \mathrm{RMSE}=81 / 08\right)$. In order to save the costs and manpower and to avoid a destructive method, the optimized output in the form of black box has the wide applicability to predict the water reserve in the mixed-beech forests to manage water cycle in the studied ecosystem.
\end{abstract}

Keywords: Artificial neural network, Carbon sink, Mixed-beech forests, Water cycle.

1. Forestry, Res. Institute of Forests and Rangelands, Agric. Res. Education and Extension Organization (AREEO), Tehran, Iran.

*: Corresponding Author, Email: ali.vahedi60@gmail.com 